\title{
Simultaneous refolding, purification, and immobilization of recombinant Fibrobacter succinogenes $1,3-1,4-\beta$-D-glucanase on artificial oil bodies
}

\author{
Yi-Fang Zeng, ${ }^{a}$ Ying-Jing Hung, ${ }^{b}$ Ming-Ju Chen, ${ }^{b}$ Chi-Chung Peng, ${ }^{c}$ \\ Jason T. C. Tzen ${ }^{d}$ and Je-Ruei Liu ${ }^{a, b *}$
}

\begin{abstract}
BACKGROUND: 1,3-1,4- $\beta$-D-glucanase (1,3-1,4- $\beta$-D-glucan 4-glucanohydrolase; EC 3.2.1.73) has been used in a range of industrial processes. As a biocatalyst, it is better to use immobilized enzymes than free enzymes, therefore, the immobilization of 1,3-1,4- $\beta$-D-glucanase was investigated.

RESULTS: A 1,3-1,4- $\beta$-D-glucanase gene from Fibrobacter succinogenes was overexpressed in Escherichia coli as a recombinant protein fused to the $\mathbf{N}$ terminus of oleosin, a unique structural protein of seed oil bodies. With the reconstitution of the artificial oil bodies (AOBs), refolding, purification, and immobilization of active 1,3-1,4- $\beta$-D-glucanase was accomplished simultaneously. Response surface modeling (RSM), with central composite design (CCD), and regression analysis were successfully applied to determine the optimal temperature and pH conditions of the AOB-immobilized 1,3-1,4- $\beta$-D-glucanase. The optimal conditions for the highest immobilized 1,3-1,4- $\beta$-D-glucanase activity $\left(7.1 \mathrm{IU} \mathrm{mg} \mathrm{m}^{-1}\right.$ of total protein) were observed at $39{ }^{\circ} \mathrm{C}$ and $\mathrm{pH} 8.8$. Furthermore, AOB-immobilized 1,3-1,4- $\beta$-D-glucanase retained more than $70 \%$ of its initial activity after 120 min at $39{ }^{\circ} \mathrm{C}$, and it was easily and simply recovered from the surface of the solution by brief centrifugation; it could be reused eight times while retaining more than $80 \%$ of its activity.
\end{abstract}

CONCLUSIONS: These results indicate that the AOB-based system is a comparatively simple and effective method for simultaneous refolding, purification, and immobilization of 1,3-1,4- $\beta$-D-glucanase.

(c) 2009 Society of Chemical Industry

Keywords: immobilization; Fibrobacter succinogenes; 1,3-1,4- $\beta$-D-glucanase; artificial oil body

\section{INTRODUCTION}

Cellulose is the primary product of photosynthesis in terrestrial environments, and the most abundant renewable bioresource produced in the biosphere. Cellulose biodegradation is very important in several agricultural and waste treatment processes. It could be widely used to produce sustainable biobased products and bioenergy to replace depleting fossil fuels. ${ }^{1}$ Cellulose can be degraded by the coordinated action of cellulolytic enzymes, such as endoglucanase, cellobiohydrolase, and $\beta$-glucosidase. Endoglucanases cleave glucosidic linkages randomly throughout cellulose molecules, while cellobiohydrolases cleave the disaccharide cellobiose from either the nonreducing or reducing end of the cellulose polymer chain. $\beta$-glucosidases hydrolyze cellobiose and low-molecular-mass cellooligosaccharides to release glucose. ${ }^{2-4}$ These three types of enzymes act cooperatively to convert cellulose into its constituent sugars. Of these, endoglucanases have received much attention because of their many applications in agricultural, industrial and environmental fields. ${ }^{5}$

1,3-1,4- $\beta$-D-glucanase (1,3-1,4- $\beta$-D-glucan 4-glucanohydrolase; EC 3.2.1.73) is an endoglucanase that specifically hydrolyzes $1,4-$ $\beta$-D-glucosidic bonds adjacent to 1,3- $\beta$-linkages in mix-linked $\beta$ - glucan, yielding mainly cellobiosyltriose and cellotriosyltetraose. ${ }^{6}$ This enzyme has received much attention in both basic and applied research, because of its enzymatic functions and importance in a range of industrial processes, such as supplemental or substitute malt enzymes in beer brewing and increasing the feed conversion efficiency and growth rates of nonruminal animals. ${ }^{6}$ If 1,3-1,4- $\beta$-Dglucanase could be recycled during the industrial applications, the cost of cellulose conversion would be significantly reduced. Several reports on the immobilization of endoglucanases have been

\footnotetext{
* Correspondence to: Je-Ruei Liu, Department of Animal Science and Technology and Institute of Biotechnology, National Taiwan University, Taiwan. E-mail:jrliu@ntu.edu.tw

a Institute of Biotechnology, National Taiwan University, Taiwan

b Department of Animal Science and Technology, National Taiwan University, Taiwan

c Department of Biotechnology, National Formosa University, Taiwan

d Graduate Institute of Biotechnology, National Chung-Hsing University, Taiwan
} 
published. $^{7-9}$ The immobilized endoglucanases were entrapped into alginate or polyacrylamide gels. ${ }^{7,8}$ However, immobilization of endoglucanase on the surface of gel beads rather than in beads is important for overcoming diffusion limitations because cellulose, which is the substrate of endoglucanase, is a macromolecule.

A recently established expression/purification system based on artificial oil bodies (AOBs) provides a novel method of enzyme immobilization. ${ }^{10,11}$ In this system, oleosin, a unique structural protein of seed oil bodies, is used as the carrier. Oleosin possesses a lipophilic segment embedded into a triacylglycerol core, with two amphipathic arms protruding on the surface of the oil bodies. Thus, the target protein can be expressed in Escherichia coli as an insoluble recombinant protein fused to the $\mathrm{N}$ - and/or C-terminus of oleosin. Stable artificial oil bodies are then constituted with triacylglycerol, phospholipid and the insoluble oleosin fusion protein. As illustrated previously, the insoluble recombinant proteins fused to oleosin tend to self-refold spontaneously when displayed on AOBs. ${ }^{12}$ Thus, this may offer an easy and efficient way to achieve renaturation and immobilization of recombinant proteins in one step. ${ }^{11}$

In the present study, the $F$. succinogenes 1,3-1,4- $\beta$-D-glucanase gene was constructed to express as an oleosin-fused protein in $E$. coli. With reconstitution of the $\mathrm{AOBs}$, refolding, purification, and immobilization of the active 1,3-1,4- $\beta$-D-glucanase was simultaneously accomplished. Response surface modeling (RSM), with central composite design (CCD), and regression analysis were then employed for the planned statistical optimization of the immobilized 1,3-1,4- $\beta$-D-glucanase activity.

\section{MATERIALS AND METHODS \\ Bacterial culture and DNA manipulation}

E. coli BL21 (DE3) (Novagene, Madison, WI) was grown at $37^{\circ} \mathrm{C}$ in Luria-Bertani (LB) broth (Difco Laboratories, Detroit, MI). Agar plates were prepared by adding agar $(1.5 \% \mathrm{w} / \mathrm{v}$; Difco) to broth. Plasmid DNA was isolated from E. coli using the alkali lysis method. ${ }^{13}$ Restriction enzymes and T4 DNA ligase (New England BioLabs Inc., Beverly, MA), were used according to the manufacturer's instructions.

\section{Construction of endoglucanase expression plasmids}

The uninterrupted DNA sequence encoding C-terminally truncated $F$. succinogenes 1,3-1,4- $\beta$-D-glucanase (GenBank accession number M33676), which has improved enzymatic activity and thermotolerance, ${ }^{6}$ was amplified by PCR from the plasmid pNZJ023 using the oligonucleotide forward primer, gluF (5' CATATGGTTAGCGCAAAGGATITAGCGG $3^{\prime}$ ) and the reverse primer, gluR (5' GCTCTTCTGCACGATTGCGGAGCAGGTTC $\left.3^{\prime}\right) .^{14}$ These two primers were designed to place an Ndel site at the $5^{\prime}$ end and a Sapl site at the $3^{\prime}$ end of the PCR product, respectively. The PCR fragments encoding 1,3-1,4- $\beta$-D-glucanase were digested with Ndel and Sapl, and then ligated with Ndel-Sapldigested plasmid pOSP2 to generate pOSP2-glu, which was then sequenced to ensure that no errors were introduced by PCR. ${ }^{12}$ The resultant plasmids were used to transform $E$. coli BL21 by standard techniques. ${ }^{14}$ Transformants were selected on LB agar plates containing ampicillin (100 $\mathrm{g} \mathrm{mL}^{-1}$ ) (Sigma Chemical Co., St Louis, MO).

\section{Expression of recombinant proteins}

E. coli BL21 transformed cells were cultured in LB broth and cell growth was then measured turbidimetrically at $600 \mathrm{~nm}$
$\left(\mathrm{OD}_{600}\right)$. To produce the recombinant protein, the overnight culture was prepared and subsequently seeded at a 1:100 dilution into $5 \mathrm{~mL}$ of fresh LB broth. The cell cultures were maintained at $37^{\circ} \mathrm{C}$ and induced with $100 \mu \mathrm{mol} \mathrm{L}^{-1}$ of isopropylL-D-thiogalactopyranoside (IPTG; Sigma) for protein production upon reaching $\mathrm{OD}_{600}$ of 0.5 . After $4 \mathrm{~h}$ of induction, the cells were harvested by centrifugation at $5000 \mathrm{~g}$ for $20 \mathrm{~min}$ at $4{ }^{\circ} \mathrm{C}$.

\section{Immobilization of 1,3-1,4- $\boldsymbol{\beta}$-D-glucanase on AOBs}

AOBs were prepared according to the method described by Chiang et al. ${ }^{12}$ The cell pellet was resuspended in $1 \mathrm{~mL}$ of $0.1 \mathrm{~mol} \mathrm{~L}^{-1}$ sodium phosphate buffer ( $\mathrm{pH} 7.4)$, sonicated for 10 min with an ultrasonicator (Model XL; Misonix, Farmingdale, NY), and fractioned into supernatant and pellet by subsequent centrifugation at $5000 \mathrm{~g}$ for $20 \mathrm{~min}$ at $4{ }^{\circ} \mathrm{C}$. AOBs were reconstituted in $1 \mathrm{~mL}$ of $0.1 \mathrm{~mol} \mathrm{~L}^{-1}$ sodium phosphate buffer $(\mathrm{pH} 7.4)$ with $15 \mathrm{mg}$ of olive oil (Sigma), $150 \mu \mathrm{g}$ of phospholipid (Sigma), and the pellet fraction of the E. coli cell lysate containing $550 \mu \mathrm{g}$ of oleosin-fused recombinant proteins. The mixture was subjected to sonication. Subsequently, the reconstituted AOBs were collected after centrifugation and washed with $0.1 \mathrm{~mol} \mathrm{~L}^{-1}$ sodium phosphate buffer solution ( $\mathrm{pH}$ 7.4). The protein production of each step was analyzed using sodium dodecyl sulfate polyacrylamide gel electrophoresis (SDS-PAGE). ${ }^{15}$

\section{1,3-1,4- $\beta$-D-glucanase activity assays}

1,3-1,4- $\beta$-D-glucanase activity on the AOBs was determined using barley $\beta$-glucan (Megazyme International, Wicklow, Ireland) as the substrate. Reducing sugar released from the substrate was estimated using the dinitrosalicylic acid (DNS) method. ${ }^{16}$ One unit of enzyme activity was defined as that releasing $1 \mu \mathrm{mol}$ of reducing sugar equivalents per minute from the substrate under the assay conditions, with specific activity expressed as $\mathrm{IU} \mathrm{mg}{ }^{-1}$ protein. Protein concentration was determined using Lowry assay against a standard curve of bovine serum albumin, fraction V (Sigma). ${ }^{17}$

\section{Optimum pH and temperature of immobilized 1,3-1,4- $\beta$-D- glucanase}

RSM, its main effects and the interaction between the different factors each at level, was simultaneously investigated. CCD with two variables at five levels and five replicates at the central point, for a total of 13 experiments were conducted. In this experimental design, $\mathrm{pH}\left(X_{1}\right)$ and temperature $\left(X_{2}\right)$ were chosen as factors, with units of 1,3-1,4- $\beta$-D-glucanase activity denoted by $Y$. According to preliminary experimental results, the experimental index number, scaled and real values are shown in Table 1 . The scaled values were defined as follows: $X_{1}=(\mathrm{pH}-9) ; X_{2}=(\mathrm{T}-40) / 10$. The experimental design, data analysis and regression model building were performed using Design Expert (version 5.07, Stat-Ease Inc., Minneapolis, MN) software. The responses, as linear, quadratic and cubic functions of the variables, were tested for adequacy and fitness using analysis of variance (ANOVA). Model analysis and the lack-of-fit test were used for selection of adequacy models. A model with $P$-values $(P>F)$ less than 0.05 was regarded as significant. The highest-order significant polynomial was selected. The lack-of-fit test was used to compare the residual and pure errors at replicated design points. The response predictor was discarded where lackof-fit was significant, as indicated by a low probability value $(P>F)$. The model with no significant lack-of-fit was selected. Predicted residual sum of the squares (PRESS) was used as a measure of the fit of the model to the points in the design. The smaller the PRESS statistic is, the better the model fits the data points. ${ }^{18}$ 
Table 1. Process variables used in the $c c d$, showing the treatment combinations and the mean experimental responses for AOBimmobilized 1,3-1,4- $\beta$-D-glucanase

\begin{tabular}{|c|c|c|c|c|c|}
\hline \multirow[b]{2}{*}{ Treatment } & \multicolumn{2}{|c|}{$\begin{array}{c}\text { Coded setting } \\
\text { levels } \\
\left(X_{1}=\mathrm{pH}\right. \\
\left.X_{2}=T\right) \\
\end{array}$} & \multicolumn{2}{|c|}{$\begin{array}{c}\text { Actual } \\
\text { levels } \\
\left(X_{1}=\mathrm{pH}\right. \\
\left.X_{2}=T\right)\end{array}$} & \multirow{2}{*}{$\begin{array}{c}\text { 1,3-1,4- } \beta \text {-D-glucanase } \\
\text { activity }^{\mathrm{a}} \text { (IU } \mathrm{mg}^{-1} \\
\text { of total protein) }\end{array}$} \\
\hline & $x_{1}$ & $x_{2}$ & $x_{1}$ & $x_{2}$ & \\
\hline 1 & -1 & -1 & 8 & 30 & 3.5 \\
\hline 2 & 0 & -1.41 & 9 & 25.9 & 2.88 \\
\hline 3 & -1.41 & 0 & 7.59 & 40 & 5.93 \\
\hline 4 & 0 & 0 & 9 & 40 & 6.93 \\
\hline 5 & 1 & 1 & 10 & 50 & 0.4 \\
\hline 6 & 0 & 0 & 9 & 40 & 6.81 \\
\hline 7 & 0 & 0 & 9 & 40 & 6.77 \\
\hline 8 & 1.41 & 0 & 10.41 & 40 & 0.306 \\
\hline 9 & 0 & 0 & 9 & 40 & 6.56 \\
\hline 10 & 1 & -1 & 10 & 30 & 2.39 \\
\hline 11 & 0 & 1.41 & 9 & 54.1 & 2.58 \\
\hline 12 & 0 & 0 & 9 & 40 & 6.73 \\
\hline 13 & -1 & 1 & 8 & 50 & 4.48 \\
\hline
\end{tabular}

After the optimal conditions for the immobilized 1,3-1,4- $\beta$ D-glucanase activity were predicted, a series of experiments were conducted in triplicate and repeated three times in order to check the reliability of the RSM with the predicted values and experimental data. The results were analyzed using ANOVA test available from the Statistical Analysis System software (SAS; version 8.1; Statistical Analysis System Institute, Cary, NC). Duncan's multiple range test was used to detect differences between the predicted and observed values. ${ }^{19}$

\section{Thermal stability of immobilized 1,3-1,4- $\beta$-D-glucanase}

The thermal stability of $\mathrm{AOB}$-immobilized 1,3-1,4- $\beta$-D-glucanase was determined by incubation at 39,50 and $60{ }^{\circ} \mathrm{C}$ in $0.1 \mathrm{~mol} \mathrm{~L}^{-1}$ Tris- $\mathrm{HCl}$ buffer ( $\mathrm{pH}$ 8.8) containing $0.5 \%$ barley $\beta$-glucan (Megazyme) as the substrate. Aliquots were withdrawn at intervals of $0,20,40,60,80,100$, and $120 \mathrm{~min}$, and the residual enzyme activity was measured.

\section{Reusability of immobilized 1,3-1,4- $\beta$-D-glucanase}

The reusability of $\mathrm{AOB}$-immobilized $1,3-1,4-\beta$-D-glucanase was determined by incubation at $39^{\circ} \mathrm{C}$ for $20 \mathrm{~min}$ in $0.1 \mathrm{~mol} \mathrm{~L}^{-1}$ Tris$\mathrm{HCl}$ buffer ( $\mathrm{pH} 8.8$ ) containing $0.5 \%$ barley $\beta$-glucan (Megazyme) as the substrate. At the end of the reaction, the immobilized enzyme was recovered by centrifugation and the supernatant was removed for further analysis. The reaction was reinitiated by administration of the recovered enzymes in a fresh substrate solution.

\section{RESULTS AND DISCUSSION}

\section{Simultaneous refolding, purification, and immobilization of 1,3-1,4- $\beta$-D-glucanase on AOBs}

The DNA fragments encoding $C$-terminally truncated $F$. succinogenes 1,3-1,4- $\beta$-D-glucanase were amplified by PCR and subcloned

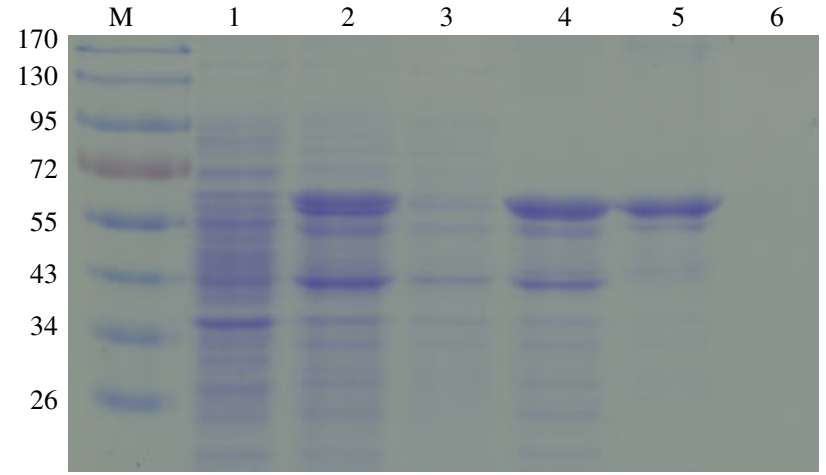

Figure 1. SDS-PAGE analysis of 1,3-1,4- $\beta$-D-glucanase immobilized on AOBs. Lane $M$, molecular weight marker; lane 1 , cell lysate of the recombinant $E$. coli before IPTG induction; lane 2, cell lysate of the recombinant $E$. coli after IPTG induction; lane 3, soluble fraction of the cell lysate after centrifugation; lane 4, insoluble fraction of the cell lysate after centrifugation; lane 5, AOBs; lane 6, remaining supernatant after AOBs recovery.

into the AOB expression/purification system vector pOSP2. 1,3$1,4-\beta$-D-glucanase was overexpressed in $E$. coli as a recombinant protein fused to the $\mathrm{N}$ terminus of oleosin by a linker polypeptide. After induction with IPTG at $37^{\circ} \mathrm{C}$, the induced and non-induced recombinant bacteria containing the 1,3-1,4- $\beta$-D-glucanase genes were analyzed using SDS-PAGE. A band of about $65 \mathrm{kDa}$ corresponding to the 1,3-1,4- $\beta$-D-glucanase-oleosin fusion protein was observed in the induced recombinant bacteria (Fig. 1, lane 2). The 1,3-1,4- $\beta$-D-glucanase-oleosin fusion protein was found predominately in the insoluble fraction of the cell lysate after centrifugation (Fig. 1, lane 4). After reconstitution into AOBs, the 1,3-1,4- $\beta$-D-glucanase-oleosin fusion protein, as well as other insoluble bacterial proteins, was almost entirely present in the oil-body fraction after centrifugation (Fig. 1, lane 6). The DNS method was then used to confirm 1,3-1,4- $\beta$-D-glucanase activity of the reconstituted AOBs. Detectable levels of 1,3-1,4- $\beta$-D-glucanase activity were observed in the reconstituted $A O B s$ from the induced recombinant bacteria, indicating that $1,3-1,4-\beta$-D-glucanase was immobilized on the AOB surface and folded into the active structure. In addition, the yield of the reconstituted $A O B$ s was $9.44 \pm 1.25$ $\mathrm{mL}$, starting from $1.5 \mathrm{~g}$ (wet weight) of $E$. coli cells, while the protein concentration of the reconstituted AOBs was $0.16 \pm 0.02 \mu \mathrm{g}$ $\mu \mathrm{L}^{-1}$.

Although the cost of commercial cellulolytic enzyme preparations has been reduced significantly in recent years, enzyme costs are still an obstacle to full-scale process commercialization. ${ }^{20}$ Immobilization on an inert carrier offers the prospect of significant cost savings by facilitating enzyme recycling through multiple cycles of batch-wise hydrolysis. Additionally, enzyme immobilization frequently results in improved thermal stability or resistance to shear inactivation. ${ }^{21}$ In the past, immobilized endoglucanases were usually entrapped into alginate or polyacrylamide gel beads. ${ }^{7,8}$ However, immobilization of endoglucanase on the surface of gel beads rather than in beads is important for overcoming diffusion limitations because the macromolecular property of the substrate cellulose restricts passage through the bead matrix. In the current study, 1,3-1,4- $\beta$-D-glucanase was fused to the $\mathrm{N}$ terminus of oleosin and then mixed with plant oil to form AOBs. The enzyme activity assay confirmed the presence of active 1,3-1,4- $\beta$-D-glucanase on the surfaces of the AOBs. Compared with conventional immobilization methods, 
Table 2. Model analysis (a), lack-of-fit (b), and R-squared analysis (c) for measured responses

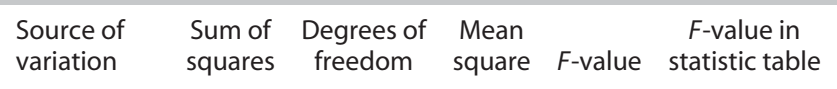

(a) Model analysis ${ }^{\mathrm{a}}$

$\begin{array}{lrrrrr}\text { mean } & 243.53 & 1 & 243.53 & & \\ \text { linear } & 21.85 & 2 & 10.93 & 2.12 & 0.1710 \\ \text { quadratic } & 50.41 & 3 & 16.80 & 99.92 & <0.0001^{* *} \\ \text { cubic } & 1.00 & 2 & 0.50 & 13.89 & 0.0091^{* *} \\ \text { residual } & 0.18 & 5 & 0.036 & & \\ \text { total } & 316.96 & 13 & 24.38 & & \\ \begin{array}{lccccc}\text { (b) Lack-of-fit } \\ \text { linear }\end{array} & 51.51 & 6 & 8.59 & 474.32 & <0.0001^{* *} \\ \text { quadratic } & 1.10 & 3 & 0.37 & 20.34 & 0.0069^{* *} \\ \text { cubic } & 0.11 & 1 & 0.11 & 5.92 & 0.0717 \\ \text { pure error } & 0.072 & 4 & 0.018 & & \end{array}$

(c) $R$-squared analysis ${ }^{c}$

\begin{tabular}{lcr} 
& R-squared & PRESS \\
\cline { 2 - 3 } Linear & 0.2976 & 83.22 \\
Quadratic & 0.9840 & 7.97 \\
Cubic & 0.9976 & 6.97
\end{tabular}

** Statistically significant at $99 \%$ of confidence level.

${ }^{a}$ Model analysis: select the highest order polynomial where the additional terms are significant.

b Lack-of-fit: want the selected model to have insignificant lack-of-fit.

${ }^{\mathrm{C}} R$-squared analysis: focus on the model minimizing the PRESS.

the use of $A O B s$ as immobilization matrices reduces the requirement for 1,3-1,4- $\beta$-D-glucanase purification and eliminates the cost of immobilization. In particular, 1,3-1,4- $\beta$-D-glucanase immobilized on AOBs can be recovered easily from the surface of the solution simply by a brief centrifugation. These results prove that $A O B$ immobilization is a comparatively simple and effective method of refolding, purification, and immobilization of 1,3-1,4- $\beta$-D-glucanase.

\section{Optimization of immobilized 1,3-1,4- $\beta$-D-glucanase activity}

Temperature and $\mathrm{pH}$ were identified as the major factors affecting the activity of 1,3-1,4- $\beta$-D-glucanase. ${ }^{6} \mathrm{RSM}$ is an empirical modeling technique used to evaluate the relationship between a set of controllable experimental factors and observed results. CCD, which minimizes the number of experimental runs, was used to determine the effects of independent variables on the dependent variables. The process variables used in the experimental design and results for enzyme activities are shown in Table 1. Treatments $4,6,7,9$ and 12 (central points) showed the highest levels of $1,3-1,4-\beta$-D-glucanase activity.

Table 2 compares the validities of the linear, quadratic and cubic models for the responses according to their F-values. The cubic model appeared to be the most accurate, with a statistically insignificant lack-of-fit $(P>0.05)$ and the smallest PRESS value (6.97). In addition, the goodness of fit of the cubic model was checked using the coefficient of determination $\left(R^{2}=0.9976\right)$, indicating that just $0.24 \%$ of the total variation was not explained by the model. This confirms that the accuracy and general ability of the cubic model was good, and analysis of the associated response trends was reasonable.
Table 3. Coefficient estimates by regression modeling

\begin{tabular}{|lcrr} 
Factor & $\begin{array}{c}\text { Coefficient } \\
\text { estimate }\end{array}$ & Standard error & $P$-value \\
\hline intercept & 6.76 & 0.085 & \\
$\mathrm{pH}^{*}$ & -0.61 & 0.210 & 0.0353 \\
$T$ & -0.40 & 0.210 & 0.1185 \\
$\mathrm{pH} \times \mathrm{pH}^{* *}$ & -1.88 & 0.072 & $<0.0001$ \\
$T \times T^{* *}$ & -2.07 & 0.072 & $<0.0001$ \\
$\mathrm{pH} \times T^{* *}$ & -0.74 & 0.095 & 0.0005 \\
$\mathrm{pH} \times \mathrm{pH} \times \mathrm{pH}^{* *}$ & -0.69 & 0.130 & 0.0036 \\
$T \times T \times T$ & 0.15 & 0.130 & 0.3243
\end{tabular}

* Statistically significant at $95 \%$ of confidence level.

** Statistically significant at $99 \%$ of confidence level.

The cubic model generated by the design is:

$$
\begin{aligned}
Y= & \beta_{0}+\beta_{1} X_{1}+\beta_{2} X_{2}+\beta_{11} X_{1}{ }^{2}+\beta_{22} X_{2}{ }^{2} \\
& +\beta_{12} X_{1} X_{2}+\beta_{111} X_{1}{ }^{3}+\beta_{222} X_{2}{ }^{3}+\varepsilon
\end{aligned}
$$

where $\beta_{0}$ is constant, $\beta_{1}$ and $\beta_{2}$ are the main effect of each process variable ( $\mathrm{pH}$ and temperature), $\beta_{11}$ and $\beta_{22}$ are effect of the square of the variables, $\beta_{12}$ is the interaction effect between the variables, $\beta_{111}$ and $\beta_{222}$ denote the effect of the cube of the variables, $Y$ is endoglucanase activity, $X_{1}$ and $X_{2}$ represent the independent variables ( $\mathrm{pH}$ and temperature), and $\varepsilon$ is the random error.

The RSM yielded the following regression equation:

$$
\begin{aligned}
Y= & 6.76-0.61 \mathrm{pH}-0.40 T-1.88 \mathrm{pH}^{2}-2.07 T^{2} \\
& -0.74 \mathrm{pH} \times T-0.69 \mathrm{pH}^{3}+0.15 T^{3}
\end{aligned}
$$

where $Y$ is the predicted response for 1,3-1,4- $\beta$-D-glucanase activity (IU mg $\mathrm{mg}^{-1}$ of total protein), and $\mathrm{pH}$ and $T$ are the coded values for $\mathrm{pH}$ and temperature (see Table 1).

The significance of the coefficients determined by Student's $t$-test and the related $P$-values are presented in Table 3 . The latter were used to check the significance of each coefficient, and also indicated the strength of the interaction between each independent variable (i.e. the smaller the $P$ value, the more significant the corresponding coefficient). ${ }^{22}$ In this study, the $P$ value of $\mathrm{pH}$, second-order $\mathrm{pH}$ and $T$, the interaction coefficient of $\mathrm{pH}$ and $T$, and third-order $\mathrm{pH}$ were significant $(P<0.05)$. The high significance of the $\mathrm{pH}$ second- and third-order model indicates that it can act as a limiting factor, with even small variations substantially altering 1,3-1,4- $\beta$-D-glucanase activity. ${ }^{23}$ The model also clearly reveals significant interactions between $\mathrm{pH}$ and $T(P<0.0001)$, therefore, treating them separately may not reflect their real influence on the 1,3-1,4- $\beta$-D-glucanase activity (e.g. optimum $\mathrm{pH}$ activity changes along with $T$ ).

The RSM for enzyme activity as a function of $\mathrm{pH}$ and temperature of the immobilized 1,3-1,4- $\beta$-D-glucanase is depicted in Fig. 2 . The results indicate that the optimal conditions for the immobilized 1,3$1,4-\beta$-D-glucanase activity occur at $39^{\circ} \mathrm{C}$ and $\mathrm{pH} 8.8$. To confirm the applicability of the model, $1,3-1,4-\beta$-D-glucanase activity at the suggested optimum conditions was determined. Under these conditions, the model predicted enzymatic activity of $6.9 \mathrm{IU} \mathrm{mg} \mathrm{mg}^{-1}$ at a confidence level of $95 \%$. The experimental enzymatic activity of $7.1 \mathrm{IU} \mathrm{mg} \mathrm{m}^{-1}$ confirmed the accuracy of the model.

1,3-1,4- $\beta$-D-glucanases are important industrial enzymes due to their potential application in a range of industrial processes. 


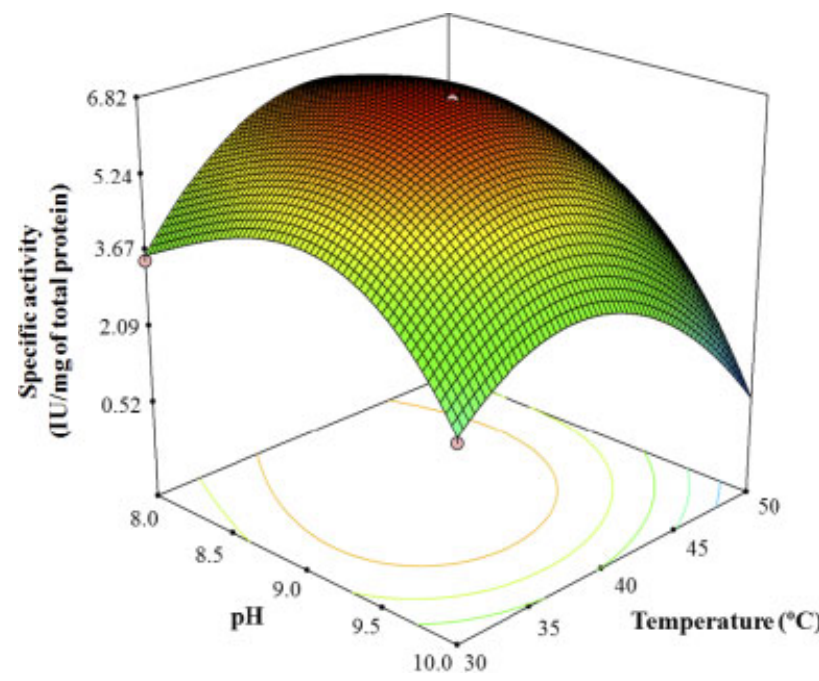

Figure 2. Response surface plot for the effects of $\mathrm{pH}$ and temperature on AOB-immobilized 1,3-1,4- $\beta$-D-glucanase activity.

However, a major drawback to their widespread use as industrial enzymes is their thermal stability during industrial processes. This has spurred considerable research into the production of more thermally stable variants. ${ }^{6}$ The $1,3-1,4-\beta$-D-glucanase used in this study is a C-terminally truncated form of $F$. succinogenes 1,3-1,4- $\beta$-D-glucanase, which has improved enzymatic activity and thermotolerance. Wen et al. ${ }^{6}$ previously determined that the optimum temperature and $\mathrm{pH}$ of the free C-terminally truncated 1,3-1,4- $\beta$-D-glucanase was $50^{\circ} \mathrm{C}$ and between $\mathrm{pH} 6$ and 8 , respectively. However, the interactions between $\mathrm{pH}$ and temperature on the C-terminally truncated $F$. succinogenes $1,3-1,4-\beta$-D-glucanase activity have never previously been evaluated. In this study, the maximum activity of immobilized 1,3-1,4- $\beta$-D-glucanase was determined at $39^{\circ} \mathrm{C}$ and $\mathrm{pH}$ 8.8. Therefore, immobilization of the 1,3$1,4-\beta$-D-glucanase on $\mathrm{AOBs}$ slightly increased the optimum $\mathrm{pH}$ but decreased the optimum temperature of the 1,3-1,4- $\beta$-D-glucanase activity.

\section{Thermal stability of immobilized 1,3-1,4- $\beta$-D-glucanase}

Thermal stability is a very important issue when considering the industrial applications of enzymes. In this study, the immobilized $1,3-1,4-\beta$-D-glucanase retained more than $70 \%$ of its initial activity after $120 \mathrm{~min}$ of heating at $39^{\circ} \mathrm{C}$ (Fig. 3). According to Wen et al., the activity of free C-terminally truncated $F$. succinogenes $1,3-1,4-\beta$-D-glucanase was reduced to $50 \%$ of maximum after $10 \mathrm{~min}$ at $50^{\circ} \mathrm{C}^{6}$ In this study, AOB-immobilized $1,3-1,4-\beta$-Dglucanase still retained more than $60 \%$ of its activity after $10 \mathrm{~min}$ of heating at $50^{\circ} \mathrm{C}$ (Fig. 3). Thus, better thermal stability was demonstrated for the immobilized 1,3-1,4- $\beta$-D-glucanase compared with the free enzyme. Chiang et al. ${ }^{11}$ immobilized Agrobacterium radiobacter $\mathrm{D}$-hydantoinase on $\mathrm{AOBs}$ and also demonstrated that the immobilized enzyme exhibited a higher thermal tolerance than the free enzyme. In addition, Li et al. ${ }^{24}$ immobilized cellulase on the outer membrane of liposomes and indicated that the liposome membrane was favorable for maintaining the activity of the cellulase in these cellulasecontaining liposomes. Therefore, we suggest that the interaction between enzyme and oil-body membrane is beneficial for reducing enzyme deactivation.

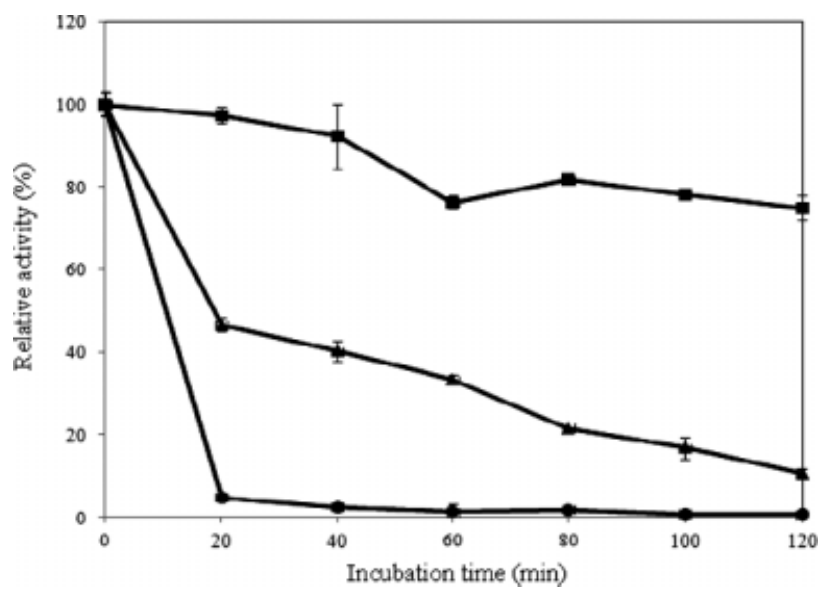

Figure 3. Thermal stability of AOB-immobilized 1,3-1,4- $\beta$-D-glucanase incubated at $39^{\circ} \mathrm{C}(\boldsymbol{\square}), 50^{\circ} \mathrm{C}(\boldsymbol{\Delta})$, or $60^{\circ} \mathrm{C}(\bullet)$ for $120 \mathrm{~min}$ in $0.1 \mathrm{~mol} \mathrm{~L}^{-1}$ Tris- $\mathrm{HCl}$ buffer ( $\mathrm{pH} 8.8$ ) containing $0.5 \%$ barley $\beta$-glucan. The bars represent standard errors of the means of triplicate measurement.

\section{Reusability of immobilized 1,3-1,4- $\beta$-D-glucanase}

Immobilized enzymes are preferred in industrial applications because in this form, they can be recycled and, thus, reduce production costs. AOBs can be separated from the reaction mixture by flotation centrifugation, thus the 1,3-1,4- $\beta$-D-glucanase immobilized on AOBs could be recovered and recycled. To evaluate this possibility, the recovery and operational stability of AOBimmobilized 1,3-1,4- $\beta$-D-glucanase was examined during eight successive rounds of $\beta$-glucan hydrolysis. The AOB-immobilized $1,3-1,4-\beta$-D-glucanase was reused for six cycles at $39^{\circ} \mathrm{C}$ without loss of activity. After that, the enzyme activity gradually declined, but still retained more than $80 \%$ of its initial activity after eight cycles of enzyme use (Fig. 4). It is interesting to note that because $1,3-1,4-\beta$-D-glucanase immobilized on AOBs floats rather than sinks, it is much easier to recover in heterogeneous mixtures containing precipitable solids, which could confound attempts to recover enzymes bound to solid matrices. However, the operational stability of enzymes must be evaluated because it is one of the most important factors affecting the success of the applications of an immobilized system. In this study, results prove that 1,3-1,4- $\beta$-D-glucanase immobilized on AOBs under optimal conditions can be reused many times, thereby reducing the cost of enzymes used in industrial processes where the cost of the enzyme is significant.

\section{CONCLUSION}

The gene encoding 1,3-1,4- $\beta$-D-glucanase from $F$. succinogenes was cloned and expressed as an oleosin-fused protein in E. coli. Simultaneous refolding, purification, and immobilization of the active 1,3-1,4- $\beta$-D-glucanase was accomplished as a result of reconstituting AOBs, and RSM with CCD and regression analysis were successfully applied to determine the optimal temperature and $\mathrm{pH}$ conditions for AOB-immobilized 1,3-1,4- $\beta$-D-glucanase. The optimal conditions for immobilized 1,3-1,4- $\beta$-D-glucanase activity were observed at $39^{\circ} \mathrm{C}$ and $\mathrm{pH}$ 8.8. In addition, the AOBimmobilized 1,3-1,4- $\beta$-D-glucanase was reused eight times while retaining more than $80 \%$ of its activity. It was recovered easily from the surface of the solution by brief centrifugation. These results prove that an AOB-based system is a comparatively simple 


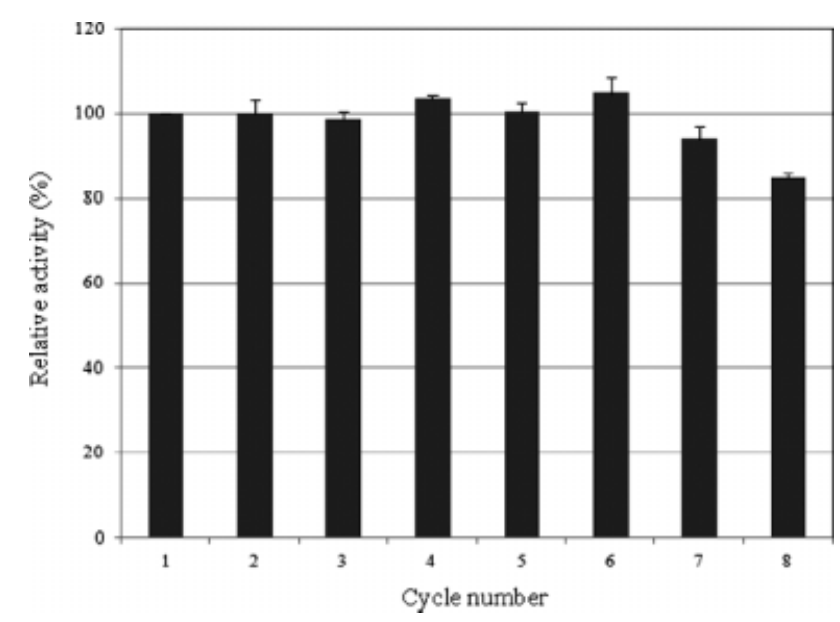

Figure 4. Reusability of the AOB-immobilized 1,3-1,4- $\beta$-D-glucanase incubated at $39^{\circ} \mathrm{C}$ for $20 \mathrm{~min}$ in $0.1 \mathrm{~mol} \mathrm{~L}^{-1}$ Tris- $\mathrm{HCl}$ buffer (pH 8.8) containing $0.5 \%$ barley $\beta$-glucan. The bars represent the standard errors of the means of triplicate measurement.

and effective method for simultaneous refolding, purification, and immobilization of 1,3-1,4- $\beta$-D-glucanase.

\section{ACKNOWLEDGEMENTS}

This research was conducted using funds partially provided by grant NSC 95-2313-B-002-118-MY3 and NSC 98-ET-E-002-001-ET from the National Science Council and grant 97AS-2.1.4-AD-U1(10) from the Council of Agriculture, Taiwan, Republic of China.

\section{REFERENCES}

1 Zhang YHP, Himmel ME and Mielenz JR, Outlook for cellulase improvement: Screening and selection strategies. Biotechnol Adv 24:452-481 (2006).

2 Denman S, Xue GP and Patel B, Characterization of a Neocallimastix patriciarum cellulase CDNA (celA) homologous to Trichoderma reesei cellobiohydrolase II. Appl Environ Microbiol 62:1889-1896 (1996).

3 Hasper AA, Dekkers E, van Mil M, van de Vondervoort PJl and de Graaff $\mathrm{LH}, \mathrm{EglC}$, a new endoglucanase from Aspergillus niger with major activity towards xyloglucan. Appl Environ Microbiol 68:1556-1560 (2002).

4 Gray KA, Zhao L and Emptage, M. Bioethanol. Curr Opin Chem Biol 10:141-146 (2006).

5 Planas, A. Bacterial 1,3-1,4- $\beta$-glucanases: structure, function and protein engineering. Biochim Biophys Acta 1543:361-382 (2000).

6 Wen TN, Chen JL, Lee SH, Yang NS and Shyur LF, A Truncated Fibrobacter succinogenes 1,3-1,4- $\beta$-D-glucanase with improved enzymatic activity and thermotolerance. Biochemistry 44:9197-9205 (2005).
7 Busto MD, Ortegan N and Perez-Mateos M, Characterization of microbial endo- $\beta$-glucanase immobilized in alginate beads. Acta Biotechnol 3:189-200 (1998).

8 Saleem M, Rashid MH, Jabbar A, Perveen R, Khalid AM and Rajoka MI, Kinetic and thermodynamic properties of an immobilized endoglucanase from Arachniotus citrinus. Process Biochem 40:849-855 (2005).

9 Rajoka MI, Zia Y and Rehman KU, A surface immobilization method of endoglucanase from cellulomonas biazotea mutant improved catalytic properties of biocatalyst during processing. Protein Pept Lett 14:734-741 (2007).

10 Peng CC, Shyu DJH, Chou WM, Chen MJ and Tzen JTC, Method for bacterial expression and purification of sesame cystatin via artificial oil bodies. J Agric Food Chem 52:3115-3119 (2004).

11 Chiang CJ, Chen HC, Kuo HF, Chao YP and Tzen JTC, A simple and effective method to prepare immobilized enzymes using artificial oil bodies. Enzyme Microb Technol 39:1152-1158 (2006).

12 Chiang CJ, Chen HC, Chao YP and Tzen JTC, Efficient system of artificial oil bodies for functional expression and purification of recombinant nattokinase in Escherichia coli. J Agric Food Chem 53:4799-4804 (2005).

13 Birnboim HC and Doly J, A rapid alkaline extraction procedure for screening recombinant plasmid DNA. NucleicAcids Res 7:1513-1517 (1979).

14 Liu JR, YuB, Liu FH, Cheng KJ and Zhao X, Expression of rumen microbial fibrolytic enzyme genes in probiotic Lactobacillus reuteri. Appl Environ Microbiol 71:6769-6775 (2005).

15 Laemmli UK, Cleavage of structural proteins during the assembly of the head of bacteriophate T4. Nature 227:680-685 (1970).

16 Konig J, Grasser R, Pikor H and Vogel K, Determination of xylanase, $\beta$-glucanase, and cellulase activity. Anal Bioanal Chem 374:80-87 (2002).

17 Lowry OH, Rosebrough NJ, Farr AL and Randall RJ, Protein measurement with the folin-phenol reagent. J Biol Chem 193:256-275 (1951).

18 Segurola J, Allen NS, Edge M and McMahon A, Design of eutectic photoinitiator blends for UV/visible curable acrylated printing inks and coatings. Prog Org Coat 37:23-37 (1999).

19 Montgomery DC, Experiments with a single factor: the analysis of variance. in Design and Analysis of Experiments, ed by Montgomery DC. John Wiley and Sons, New York, pp 75-77 (1999).

20 Lynd LR, van Zyl WH, McBride JE and Laser M, Consolidated bioprocessing of cellulosic biomass: an update. Curr Opin Biotechnol 16:577-583 (2005)

21 Tu M, Zhang X, Kurabi A, Gilkes N, Mabee W and Saddler J, Immobilization of $\beta$-glucosidase on Eupergit $C$ for lignocellulose hydrolysis. Biotechnol Lett 28:151-156 (2006).

22 Akhnazarova S and Kafarov V, Experiment Optimization in Chemistry and Chemical Engineering. Mir Publishers, Moscow (1982).

23 Heck JX, Flôres SH, Hertz PF and Ayub MAZ, Statistical optimization of thermo-tolerant xylanase activity from Amazon isolated Bacillus circulans on solid-state cultivation. Bioresources Technol 97:1902-1906 (2006).

24 Li C, Yoshimoto M, Fukunaga K and Nakao K, Characterization and immobilization of liposome-bound cellulase for hydrolysis of insoluble cellulose. Bioresources Technol 98:1366-1372 (2007). 